Jurnal Ilmu Ilmu Agribisnis: Journal of Agribusiness Science, 9(4), November 2021

\title{
ANALISIS PENDAPATAN RUMAH TANGGA PETANI DAN KEBERLANJUTAN REPONG DAMAR DI KECAMATAN PESISIR TENGAH KABUPATEN PESISIR BARAT
}

(Income and Sustainability Analysis Repong Damar in Central Coastal Subdistrict West Pesisir Regency)

Fibriand Andika, Dwi Haryono, Sumaryo Gitosaputro

Jurusan Agribisnis, Fakultas Pertanian, Universitas Lampung, Jl. Prof. Dr. Soemantri Brodjonegoro No. 1

Bandar Lampung 35141, e-mail: dwi.haryono@fp.unila.ac.id

\begin{abstract}
This study aimed to determine forming income, the income of farmer households, and the sustainability of repong damar at Pahmungan Village, Central Pesisir Subdistrict, West Pesisir District. The method used in this research was the survey method. Primary and secondary data were collected in this study. The Sampling used census sampling. The number of respondents consisted of 58 farmers of repong damar. This study took approximately two months, starting from March to April 2018. The results of this study indicate that repong damar farming provides benefits and was feasible to run based on the results of the $R / C$ has a value of $>1$. The household income of repong damar farmers was IDR 48,657,130.03 per year, the largest contribution comes from on-farm income with a percentage of 85.10 percent. Repong damar farming at Pahmungan Village, Central Pesisir Subdistrict, West Pesisir District was considered sustainable from social, ecological, and economic aspects.
\end{abstract}

Key words: household income, income, repong damar, sustainability.

Received: 1 September $2020 \quad$ Revised: 3 December $2020 \quad$ Accepted:18 December $2020 \quad$ DOI: http://dx.doi.org/10.23960/jiia.v9i4.5403

\section{PENDAHULUAN}

Indonesia merupakan negara agraris yang mayoritas penduduknya hidup dari bertani. Pertanian merupakan sektor yang berperan penting dalam mewujudkan kesejahteraan kehidupan penduduk yang tinggal di daerah pedesaan (Ario 2010). Menurut Badan Pusat Statistik (2017), penduduk Indonesia paling banyak bekerja di sektor pertanian yaitu sebanyak 31,86 persen. Secara umum, penduduk pedesaan memenuhi kebutuhan hidupnya, sangat bergantung pada pemanfaatan alam lingkungannya.

Provinsi Lampung merupakan provinsi di Indonesia yang memiliki kekayaan sumberdaya alam yang melimpah. Salah satu kekayaan alam yang masih lestari dengan kearifan lokalnya adalah repong damar yang ada di Pekon Pahmungan Pesisir Barat yang masih membudidayakan repong damar sebagai salah satu mata pecaharian utama petani. Repong dalam terminologi masyarakat Pesisir Barat yaitu sebidang lahan kering yang ditumbuhi beranekaragam jenis tanaman produktif dari beragam jenis kayu yang bernilai ekonomis sampai beragam jenis tumbuhan liar yang dibiarkan hidup membangun suatu kesatuan sistem ekologis disebut repong damar, karena pohon damar (Shorea javanica) merupakan tegakan yang dominan jumlahnya pada setiap bidang repong (Lubis 1997).

Damar merupakan komoditas unggulan Kabupaten Pesisir Barat. Di Provinsi Lampung, damar hanya terdapat di Kabupaten Pesisir Barat. Damar merupakan salah satu tanaman kayu asli Indonesia yang tersebar di Sumatera, Kalimantan, Sulawesi, Maluku dan Papua. Damar biasanya dimanfaatkan kayunya karena mempunyai nilai jual yang cukup tinggi, terutama digunakan untuk pertukangan pohon-pohon suku meranti-rantian Dipterocarpaceae ini tumbuh dominan di hutan dataran rendah Asia Tenggara, karena itu damar merupakan jenis resin yang lazim dikenal di Indonesia Bagian Barat (Michon et al.1994).

Kabupaten Pesisir Barat menghasilkan getah damar dengan kualitas nomor satu yang dikenal dengan getah damar "Mata Kucing". Menurut Michon et al. (1994) repong damar telah dibudidayakan masyarakat Pesisir Barat sejak zaman Belanda hingga sekarang. Damar menjadi salah satu bagian dari sistem usaha tani masyarakat setempat, seperti halnya budidaya tanaman lain (Makmur, Imron dan Maskun 2013).

Pohon damar merupakan tanaman yang sudah ditanam sejak tahun 1700-an dan telah menjadi sistem budidaya secara turun temurun, repong damar tidak bisa dilepaskan dari kehidupan 
masyarakat Pesisir Barat. Dalam pengelolaannya, pohon damar disadap getahnya dan tegakannya tetap dipertahankan, sehingga masih banyak ditemukan pohon damar yang berumur ratusan tahun. Fakta ini cukup membuktikan bahwa sistem budidaya hutan ini mempunyai indikator keberlanjutan yang kuat. Keberlanjutan sistem budidaya damar dipandang mampu menopang kehidupan sosial ekonomi masyarakat yang bernaung di dalamnya. Pada Tahun 1995, tidak kurang dari 79 persen penduduk di wilayah Pesisir Krui dapat menggantungkan kehidupan mereka terhadap repong damar (Lensary 2011).

Pekon Pahmungan terletak di Kecamatan Pesisir Tengah, Kabupaten Pesisir Barat, Provinsi Lampung, memiliki luas areal mencapai 2.600 hektar. Kawasan Pekon Pahmungan dibedakan menjadi dua, bagian datar dan berlereng. Bagian areal yang datar meliputi 40 ha untuk persawahan, 25 ha untuk permukiman areal yang berlereng umumnya didominasi oleh tanaman damar, baik repong damar yang masih muda $(<20$ tahun dan belum diambil getahnya), maupun damar tua $(>20$ tahun dan sudah diambil getahnya) (Pekon Pahmungan 2017).

Pekerjaan sebagai petani damar umumnya merupakan hasil warisan dari para orang tua yang ada di Pekon Pahmungan, karena tanaman damar merupakan tanaman yang memiliki umur yang lama untuk bisa dipanen dan merupakan tanaman utama yang diusahakan para orang tua dulu untuk mendapat penghasilan yang memiliki nilai jual yang tinggi.

Adanya ketergantungan terhadap pendapatan dari hasil getah damar yang dijual dalam menentukan tingkat kesejahteraan hidup petani dan generasi penerusnya. Berdasarkan permasalahan yang ada, maka tujuan dari penelitian ini adalah menganalisis pendapatan usahatani, pendapatan rumah tangga petani, dan keberlanjutan repong damar di Kabupaten Pesisir Barat.

\section{METODE PENELITIAN}

Metode yang digunakan dalam penelitian ini adalah metode survei. Data primer diperoleh dari wawancara menggunakan kuesioner yang telah dibuat sebelumnya. Penelitian ini dilaksanakan di Desa Pahmungan, Kecamatan Pesisir Tengah Kabupaten Pesisir Barat. Lokasi penelitian ditentukan secara sengaja (purposive) dengan pertimbangan Desa Pahmungan merupakan desa yang merupakan penghasil damar terbesar di Kabupaten Pesisir Barat.

Responden adalah petani yang menerapkan tanaman berbasis repong damar. Jumlah populasi petani responden yang didapat adalah 58 orang. Penentuan sampel dilakukan secara sensus, karena jumlah responden kurang dari 100 (Sugiarto 2003). Pengumpulan data penelitian dilakukan pada Bulan Maret-April 2018. Metode analisis data yang digunakan dalam penelitian ini adalah deskriptif kuantitatif.

Pendapatan usahatani diperoleh dengan menghitung selisih antara penerimaan yang diterima dari hasil usahatani pada masing-masing pola tanam dengan total biaya produksi yang dikeluarkan. Penerimaan dipengaruhi oleh jumlah produksi yang dihasilkan dan tingkat harga yang berlaku. Untuk menghitung pendapatan dari usahatani usahatani repong damar digunakan rumus (Rahim dan Hastuti 2007), yaitu:

$\pi=\mathrm{TR}-\mathrm{TC}$

$\pi=$ Y.Py $-\sum X i$.Pxi-BTT.

Keterangan :

$\pi \quad=$ Pendapatan bersih $/$ keuntungan

$\mathrm{Y} \quad=$ Jumlah produksi yang dihasilkan dari usahatani i

Py $\quad=$ Harga per satuan produksi

$\mathrm{Xi}=$ Faktor produksi variabel $(\mathrm{i}=1,2,3, \ldots$,

n)

Pxi = Harga faktor produksi variabel $(\mathrm{i}=1,2,3, \ldots, \mathrm{n})$

BTT = Biaya tetap total

TR $=$ Total penerimaan

$\mathrm{TC}=$ Total biaya

Perhitungan R/C dilakukan untuk mengetahui apakah usahatani pola tanam yang dilakukan petani menguntungkan atau tidak bagi petani menggunakan rumus berikut:

$\mathrm{R} / \mathrm{C}=\frac{\mathrm{TR}}{\mathrm{TC}}$

Keterangan :

$\mathrm{R} / \mathrm{C}=$ Nisbah antara penerimaan dengan biaya

$\mathrm{TR}=$ Penerimaan kotor

$\mathrm{TC}=$ Biaya produksi total (hasil penjumlahan biaya tetap dan biaya variabel)

Terdapat tiga kemungkinan hasil yang diperoleh dengan perhitungan di atas, yaitu: 
a. Jika $\mathrm{R} / \mathrm{C}>1$, maka usahatani yang dilakukan menguntungkan

b. Jika $\mathrm{R} / \mathrm{C}=1$, maka usahatani yang dilakukan berada pada titik impas.

c. Jika $\mathrm{R} / \mathrm{C}<1$, maka usahatani yang dilakukan tidak menguntungkan (Soekartawi 1995).

Pendapatan rumah tangga petani diperoleh dengan cara menjumlahkan pendapatan keluarga yang berasal dari usahatani dan pendapatan keluarga yang berasal dari luar usahatani. Menghitung pendapatan rumah tangga petani menggnakan rumus menurut Suratiyah (2009) sebagai berikut:

Prt $=$ Pon farm + P off farm + P non farm ........(4)

$\begin{array}{ll}\begin{array}{l}\text { Keterangan : } \\ \text { Prt }\end{array} & \text { Pendapatan rumah tangga usahatani } \\ & \text { repong damar } \\ \mathrm{P} \text { on farm } & \text { Pendapatan dari usahatani repong } \\ & \text { damar } \\ \mathrm{P} \text { off farm }= & \text { Pendapatan dari luar usahatani } \\ & \text { repong damar } \\ \mathrm{P} \text { non-farm }= & \text { Pendapatan dari luar usahatani }\end{array}$

Analisis indeks keberlanjutan diperoleh dari penilaian indikator pada skala likert. Skala likert digunakan pada pertanyaan tertutup yang diberikan skor pada indikator-indikator yang dijadikan bahan uji penelitian sesuai standar indikator keberlanjutan sebelum indikator-indikator digunakan untuk mewakili jawaban penelitian. Jumlah pertanyaan yang diberikan adalah 55 pertanyaan dan dilakukannya uji validitas dan reliabilitas pada jawaban 58 responden petani dengan taraf kepercayaan 5\%. Uji validitas digunakan untuk mengetahui keabsahan alat ukur, sehingga mampu mengukur secara akurat, sedangkan uji reliabilitas digunakan untuk mengetahui konsistensi setiap indikator sebagai alat ukur, sehingga hasil pengukurannya dapat dipercay (Thamrin, Sutjahjo, Herison, dan Biham 2007).

Kategori untuk menentukan tingkat keberlanjutan usahatani repong damar berdasarkan skor skala likert 1-5 dengan skor paling kecil 1 dan paling besar adalah 5 disajikan pada :

1. Sangat Berkelanjutan (SB) (80-100 persen)

2. Berkelanjutan (B) (60-79,99 persen)

3. Cukup Berkelanjutan (CB) (40-59,99 persen)

4. Tidak Berkelanjutan (TB) (20-39,99 persen)

5. Sangat Tidak Berkelanjutan (STB) (0-19,99 persen)

\section{HASIL DAN PEMBAHASAN}

\section{Karakteristik Petani Responden}

Responden pada penelitian ini adalah petani yang menerapkan tanaman repong damar. Rata-rata usia petani responden berkisar antara 15-65 tahun dengan persentase sebesar 89 persen, usia petani tersebut termasuk dalam usia produktif. Tingkat pendidikan yang menerapkan tanaman repong damar tergolong tinggi dengan persentase tamatan SMA sebesar 46,55 persen. Jenis pekerjaan sampingan berasal dari sektor pertanian (off farm) dan non-farm. Pekerjaan sampingan petani repong damang di bidang pertanian (off farm), yaitu sebagai buruh tani, sedangkan pekerjaan sampingan non pertanian (non farm) adalah pedagang, pengusaha, PNS, dan buruh lepas. Jumlah tanggungan anggota keluarga petani antara 4-5 orang dengan persentase sebesar 55 persen, sisanya 35 persen adalah petani dengan jumlah tanggungan keluarga antara 2-3 orang. Rata-rata luas kepemilikan lahan petani responden repong damar sebesar 2,6 ha.

\section{Pendapatan Usahatani Repong Damar}

Petani di Desa Pahmungan membudidayakan tanaman damar sebagai tanaman utama dan mengkombinasikan dengan tanaman lain dengan sistem tumpang sari yang terdiri dari durian, petai, dan duku, sehingga jenis produksi yang dihasilkan dari usahatani repong damar juga beragam yaitu produksi yang berasal dari tanaman utama berupa damar, serta hasil produksi tanaman lainnya.

Pendapatan usahatani repong damar merupakan hasil pengurangan antara penerimaan dan biaya biaya yang dikeluarkan oleh petani. Analisis pendapatan usahatani repong damar dilakukan untuk dapat mengetahui apakah usahatani tersebut menguntungkan atau tidak. Rata-rata penerimaan, biaya produksi dan keuntungan petani pada repong damar di Desa Pahmungan Kecamatan Pesisir Tengah Kabupaten Pesisir Barat 2019 disajikan dalam Tabel 1.

Pendapatan usahatani repong damar dalam kurun waktu satu tahun terakhir dibedakan menjadi dua, yaitu pendapatan atas biaya tunai dan pendapatan atas biaya total. Tabel 1 menunjukkan bahwa pendapatan usahatani repong damar atas biaya. 
Jurnal Ilmu Ilmu Agribisnis: Journal of Agribusiness Science, 9(4), November 2021

Tabel 1. Rata-rata penerimaan, biaya produksi, dan keuntungan repong damar di Desa Pahmungan Kecamatan Pesisir Tengah Kabupaten Pesisir Barat 2019

\begin{tabular}{|c|c|c|c|c|c|c|}
\hline \multirow[b]{2}{*}{ No } & \multirow[b]{2}{*}{ Uraian } & \multicolumn{3}{|c|}{ Usahatani per 2,4 ha } & \multicolumn{2}{|c|}{ Usahatani per 1 ha } \\
\hline & & Produksi & $\begin{array}{c}\text { Harga } \\
\text { (Rp) }\end{array}$ & $\begin{array}{c}\text { Penerimaan } \\
(\mathrm{Rp})\end{array}$ & Produksi & $\begin{array}{c}\text { Penerimaan } \\
(\mathrm{Rp})\end{array}$ \\
\hline \multirow[t]{6}{*}{1} & Penerimaan & & & & & \\
\hline & $\begin{array}{l}\text { a. Tanaman Utama } \\
\text { - Damar } \\
\text { b. Tanaman Tumpang Sari }\end{array}$ & $1.952,59$ & $16.068,64$ & $31.375 .395,18$ & 813,58 & 13.073.081,32 \\
\hline & - Duku & $1.640,34$ & $7.042,66$ & $11.552 .388,82$ & 683,48 & 4.813.495,34 \\
\hline & - Petai & 709,00 & $17.500,00$ & $12.407 .500,00$ & 295,42 & $5.169 .791,67$ \\
\hline & - Durian & 29,71 & $35.312,50$ & $1.049 .024,78$ & 12,38 & $437.093,66$ \\
\hline & Jumlah & & & $55.384 .308,78$ & & $23.493 .461,99$ \\
\hline \multirow[t]{11}{*}{2} & Biaya Tunai & & & & & \\
\hline & Pajak & & & $225.000,00$ & & $93.750,00$ \\
\hline & Pupuk : & & & & & \\
\hline & Pupuk Urea & 25,86 & $2.243,75$ & $58.028,02$ & 10,78 & $24.178,34$ \\
\hline & Pupuk NPK & 22,41 & $2.633,33$ & $59.022,99$ & 9,34 & $24.592,91$ \\
\hline & Pupuk Kandang & 327,59 & 638,46 & $209.151,19$ & 136,49 & $87.146,33$ \\
\hline & Pestisida : & & & & & \\
\hline & Roundup & 2,17 & $80.000,00$ & $173.333,33$ & 0,90 & $72.222,22$ \\
\hline & Gramaxone & 1,96 & $65.000,00$ & $127.291,67$ & 0,82 & $53.038,19$ \\
\hline & TK Luar Keluarga & 2,38 & $3.540 .000,00$ & $8.422 .758,62$ & 0,99 & $3.509 .482,76$ \\
\hline & Total Biaya Tunai & & & $9.274 .585,82$ & & $3.864 .410,76$ \\
\hline \multirow[t]{6}{*}{3} & Biaya Diperhitungkan & & & & & \\
\hline & TK Dalam Keluarga & 2,60 & 3.908 .276 & $10.174 .994,05$ & 1,08 & $4.239 .580,86$ \\
\hline & Sewa Lahan & & & 7.165.384,61 & & $2.985 .576,92$ \\
\hline & Penyusutan Alat & & & $92.379,31$ & & $38.491,38$ \\
\hline & Total Biaya Diperhitungkan & & & $17.432 .757,98$ & & $7.263 .649,16$ \\
\hline & Total Biaya & & & $26.707 .343,80$ & & $11.128 .059,91$ \\
\hline 4 & Pendapatan atas Biaya Tunai & & & 47.109.722,96 & & $19.629 .051,23$ \\
\hline 5 & Pendapatan atas Biaya Total & & & $29.676 .964,99$ & & $12.365 .402,08$ \\
\hline 6 & $\mathrm{R} / \mathrm{C}$ atas Biaya Tunai & & & 6,08 & & 6,08 \\
\hline 7 & $\mathrm{R} / \mathrm{C}$ atas Biaya Total & & & 2,11 & & 2,11 \\
\hline
\end{tabular}

tunai per 2,40 hektar adalah Rp47.109.722,96 per tahun. Pendapatan usahatani repong damar per hektar adalah Rp19.629.051,23 per tahun. Pendapatan usahatani repong damar atas biaya total per 2,40 hektar adalah sebesar Rp29.676.964,99 per tahun dan per hektar adalah Rp12.365.402,08 per tahun. Jika dilihat dari sisi pendapatan atas biaya total, maka usahatani repong damar menguntungkan bagi petani. Perhitungan $\mathrm{R} / \mathrm{C}$ dilakukan untuk mengetahui apakah usahatani repong damar di Pekon Pahmungan Kecamatan Pesisir Tengah menguntungkan atau tidak.

$\mathrm{R} / \mathrm{C}$ memiliki nilai lebih besar dari satu $(\mathrm{R} / \mathrm{C}>1)$, hal tersebut menunjukkan bahwa usahatani repong damar di Pekon Pahmungan Kecamatan Pesisir Tengah menguntungkan. Hasil $\mathrm{R} / \mathrm{C}$ atas biaya tunai per hektar adalah 6,08 per tahun dan $\mathrm{R} / \mathrm{C}$ atas biaya total per hektar adalah 2,11 per tahun, artinya untuk setiap biaya tunai yang dikeluarkan petani sebesar satu rupiah per hektar. Petani tersebut dapat memperoleh penerimaan sebesar Rp6,08 dan untuk setiap biaya total yang dikeluarkan petani sebesar satu rupiah memperoleh penerimaan sebesar Rp2,11. Hasil ini sesuai dengan hasil penelitian Gusti, Haryono dan Prasmatiwi (2013). Gusti dkk (2013) menyatakan bahwa R/C yang diperoleh Rp2,18. Hal tersebut menunjukan kesamaan usahatani sejenis yang dijalankan di daerah lain.

Tabel 3 diketahui bahwa repong damar memiliki keuntungan usahatani dengan keuntungan sebesar Rp12.365.402,08/ha/tahun dengan nilai R/C sebesar 2,11 yang berarti bahwa setiap Rp1.000,00 biaya yang dikeluarkan akan diperoleh penerimaan sebesar Rp2.110,00. 
Tabel 2. Rekapitulasi penerimaan, biaya produksi keuntungan dan $\mathrm{R} / \mathrm{C}$ pada masing-masing pola tanam per ha per tahun di Desa Pahmungan Tahun 2017

\begin{tabular}{lr}
\hline Kegiatan Produksi & \multicolumn{1}{c}{$\begin{array}{c}\text { Repong Damar } \\
\text { (Rp/ha/tahun) }\end{array}$} \\
\hline Penerimaan & $23.493 .461,99$ \\
Biaya & $3.864 .410,76$ \\
Keuntungan & $12.365 .402,08$ \\
R/C & 2,11 \\
\hline
\end{tabular}

\section{Pendapatan Rumah Tangga Petani Repong Damar}

Pendapatan usahatani di luar budidaya (off farm) merupakan pendapatan yang diperoleh petani dari kegiatan di luar on farm. Seluruh petani melakukan kegiatan off farm sebagai pedagang pengepul dan buruh tani demi menambah pendapatan rumah tangga. Kegiatan sebagai buruh tani memiliki pendapatan sebesar Rp60.000,00 sampai dengan Rp80.000,00 per hari bagi buruh pria dan wanita, sedangkan pendapatan pedagang pengepul beragam. Rata-rata total pendapatan yang diperoleh dari luar usahatani (off farm) adalah sebesar Rp2.341.016,95 per tahun, dimana pendapatan pedagang pengepul merupakan pendapatan di luar usahatani terbesar yaitu sebesar Rp1.793.103,45 per tahun.

Pendapatan dari luar pertanian diperoleh petani dari berbagai jenis pekerjaan yang dilakukan oleh petani. Jenis pekerjaan tersebut adalah pedagang, perangkat desa, dan buruh non pertanian. Ratarata total pendapatan yang diperoleh dari luar pertanian adalah sebesar Rp4.869.310,34 per tahun. Pendapatan pedagang yaitu sebesar Rp2.303.793,10 per tahun. Pendapatan buruh lepas yaitu sebesar Rp1.489.655,17 per tahun. Pendapatan pegawai swasta yaitu sebesar Rp372.413,79 per tahun dan pendapatan perangkat desa yaitu sebesar Rp703.448,28 per tahun.

Rata-rata pendapatan rumah tangga petani repong damar di Pekon Pahmungan Kecamatan Pesisir Tengah adalah sebesar Rp48.657.130,03 per tahun, bila dikonversikan kedalam pendapatan per kapita per bulan, maka pendapatan per kapita per bulan rumah tangga petani repong damar adalah Rp1.218.529,16. Hal ini sejalan dengan hasil penelitian Bella, Abidin dan Widjaya (2019). Menurut Bella et al. (2019), rata rata pendapatan rumah tangga petani Tahura WAR di Desa Wiyono Rp33.833.424,17 per tahun, bila dikonversikan ke dalam pendapatan per kapita per bulan adalah
Rp727.603,49. Pendapatan tersebut lebih besar daripada pendapatan rumah tangga petani hutan kemasyarakatan di Kecamatan Sumberjaya Kabupaten Lampung Barat pada penelitian Damora, Anwar, dan Heryatno (2008) yaitu sebesar Rp509.626,00 per kapita per bulan.

Tabel 3 menunjukan bahwa petani di Desa Pahmungan masih bergantung pada pendapatan dari pertanian. Kontribusi pendapatan petani damar sebesar 85,10 persen pada kegiatan budidaya (on fam), sebesar 4,90 persen pada kegiatan diluar budidaya (off farm), dan sebesar 10,00 persen pada kegiatan non farm. Hasil ini sesuai dengan hasil penelitian Kharisma, Widjaya dan Kasymir (2019). Kharisma et al. (2019) menyatakan petani di Kelurahan Tejosari masih bergantung pada pendapatan dari sumber pertanian yaitu sebesar 54,29 persen pada budidaya (on farm) dan sebesar 14,03 persen pada luar buidaya (off farm) petani yang masih bergantung pada pendapatan sektor pertanian tanpa memiliki pendapatan yang berasal dari sektor non-pertanian.

\section{Keberlanjutan Repong Damar di Kabupaten Pesisir Barat}

Analisis keberlanjutan repong damar dilakukan untuk melihat keberlanjutan usaha tani repong damar yang berkelanjutan dapat ditinjau dari tiga aspek, yaitu sosial, ekologis, dan ekonomi yang diukur dengan indeks keberlanjutan, dan akan dinilai status keberlanjutannya, apakah sangat berkelanjutan (SB), berkelanjutan (B), cukup berkelanjutan (CB), tidak berkelanjutan (TB) dan sangat tidak berkelanjutan (STB).

Tabel 3. Struktur pendapatan rumah tangga petani repong damar di di Desa Pahmungan Tahun 2017

\begin{tabular}{lcc}
\hline $\begin{array}{l}\text { Sumber Pendapatan } \\
\text { Petani Repong Damar }\end{array}$ & $\begin{array}{c}\text { Pendapatan } \\
\text { (Rp/tahun) }\end{array}$ & $\begin{array}{c}\text { Persentase } \\
(\%)\end{array}$ \\
\hline $\begin{array}{l}\text { Pendapatan usahatani } \\
\text { repong damar }\end{array}$ & $31.301 .698,99$ & 64,33 \\
$\begin{array}{l}\text { Pendapatan usahatani } \\
\text { non repong damar }\end{array}$ & $10.104 .741,38$ & 20,77 \\
$\begin{array}{l}\text { Pendapatan usahatani } \\
\text { diluar kegiatan } \\
\text { budidaya (off farm) }\end{array}$ & $2.381 .379,31$ & 4,90 \\
$\begin{array}{l}\text { Pendapatan dari } \\
\text { usaha non pertanian } \\
\text { (non farm) }\end{array}$ & $4.869 .310,34$ & 10,00 \\
\hline Jumlah & $48.657 .130,03$ & 100,00 \\
\hline
\end{tabular}


Aspek sosial merupakan hubungan antar manusia yang ada di masyarakat beserta kebiasaan yang dapat berpengaruh terhadap keberlanjutan usahatani repong damar, baik secara langsung maupun tidak langsung. Keberlanjutan aspek sosial dapat dilihat dengan tiga indikator, yaitu indikator sosial budaya, manajemen sosial, dan kelembagaan. Usahatani repong damar dilihat dari aspek sosial baik dari aspek sosial budaya, manajemen sosial, maupun kelembagaan termasuk dalam kategori berkelanjutan dengan persentase 70,16 persen.

Keberlanjutan ekologis merupakan upaya untuk mempertahankan kemampuan tanah agar menghasilkan produksi optimal dalam jangka waktu yang panjang. Melalui pengelolaan lahan terpadu diharapkan dapat memelihara dan

Tabel 4. Rekapitulasi persentase keberlanjutan repong damar berdasarkan aspek sosial, ekologis dan ekonomi di Kabupaten Pesisir Barat

\begin{tabular}{llcl}
\hline No & Aspek & $\begin{array}{c}\text { Persentase } \\
(\%)\end{array}$ & Kategori \\
\hline 1 & Sosial & 70,16 & Berkelanjutan \\
2 & Ekologis & 72,86 & Berkelanjutan \\
3 & Ekonomi & 71,17 & Berkelanjutan \\
\hline
\end{tabular}

mendorong peningkatan fungsi sumber daya alam secara lestari dan yang berkelanjutan tanpa merusak lingkungan di sekelilingnya. Keberlanjutan ekologis dapat dilihat berdasarkan lima aspek, yaitu ekologi, budidaya tanaman sehat, pelestarian dan pemanfaatan musuh alami, pengetahuan petani mengenai PHT, serta kearifan lokal. Berdasarkan hasil penelitian, aspek ekologi mendapatkan persentase sebesar 72,86 persen termasuk kategori berkelanjutan. Hal ini berarti ditinjau dari aspek ekologis usahatani repong damar termasuk ke dalam kategori berkelanjutan.

Pola pertanian yang dikembangkan menjadi lebih efektif dan efisien dapat mempengaruhi kesehatan finansial dan penekanan biaya dalam usahatani, sehingga keuntungan yang diperoleh bisa maksimal. Fakta di lapangan ditinjau dari sisi ekonomi kegiatan repong damar dapat memberikan lapangan pekerjaan baru. Hasil penelitian menunjukkan bahwa para petani mendapatkan manfaat ekonomi dari hasil pengolahan repong damar dengan tingkat persentase 71,17 persen untuk melanjutkan pengolahan repong damar. Hal ini berarti dilihat dari aspek ekonomi keberlanjutan usahatani repong damar aspek ekonomi termasuk dalam kategori berkelanjutan

\section{KESIMPULAN}

Usahatani repong damar di Pekon Pahmungan Kecamatan Pesisir Tengah memberikan keuntungan dan layak untuk dijalankan berdasarkan hasil dari perhitungan $\mathrm{R} / \mathrm{C}$ repong damar yang memiliki nilai $>1$. Pendapatan rumah tangga petani repong damar adalah sebesar Rp47.109.722,96 per tahun, kontribusi terbesar berasal dari pendapatan on farm dengan persentase sebesar 85,10 persen. Usahatani repong damar di Pekon Pahmungan kecamatan Pesisir Tengah termasuk kategori berkelanjutan dilihat dari aspek sosial, ekologis, dan ekonomi.

\section{DAFTAR PUSTAKA}

Ario. 2010. Мепијu Swasembada Pangan, Revolusi Hijau II: Introduksi Managemen Dalam Pertanian. RBI. Jakarta.

Bella P, Abidin Z, dan Widjaya S. 2019. Pendapatan dan pola konsumsi rumah tangga petani sekitar Tahura Wan Abdul Rachman di Desa Wiyono Kecamatan Gedong Tataan. JIIA, $\quad 7 \quad$ (4): $\quad 529-536$ https://jurnal.fp.unila.ac.id/index.php/ Jia/Article/View/4053/2949\#, [1 September 2020].

BPS [Badan Pusat Statistik]. 2017. Statistik Indonesia. Badan Pusat Statistik. Jakarta.

Damora ASU, Anwar F, dan Heryatno Y. 2008. Pola konsumsi pangan rumah tangga petani hutan kemasyarakatan di Kabupaten Lampung Barat. Jurnal Gizi dan Pangan, 3 (3): 227232. http://journal.ipb.ac.id/jgizipangan/. [12 Juli 2019].

Gusti AI. Haryono D, dan Prasmatiwi FE. 2013. Pendapatan rumah tangga petani kakao di Desa Pesawaran Indah Kecamatan Padang Cermin Kabupaten Pesawaran. JIIA, 1 (4): 278-283. https://Jurnal.Fp.Unila.Ac.Id/Index.Php/Jia/Ar ticle/View/701/643\#. [1 September 2020]

Kharisma SS, Widjaya S, dan Kasymir E. 2019. Analisis pendapatan usahatani dengan pola tanam padi-padi-jagung dan padi-padisemangka di Kelurahan Tejosari Kecamatan Metro Timur Kota Metro. JIIA, 8 (2): 195-202 https://jurnal.fp.unila.ac.id/index.php/jia/articl e/view/4053/2949\#, [1 September 2020\}

Lensary D. 2011. Kinerja pengelolaan repong damar ditinjau dari aspek ekologi, sosial dan 
Jurnal Ilmu Ilmu Agribisnis: Journal of Agribusiness Science, 9(4), November 2021

ekonomi. Tesis. Institut Pertanian Bogor. Bogor.

Lubis Z. 1997. Repong Damar: Kajian Tentang Penganbilan Keputusan dalam Pengelolaan Lahan Hutan di Pesisir Krui, Lampung Barat. Center For International Foresty Research. Bogor.

Makmur E, Imron, Ali, dan Maskun. 2018. Repong damar bagi masyarakat pesisir di Kecamatan Karya Penggawa Kabupaten Pesisir Barat. FKIP Universitas Lampung. Bandar Lampung.

Michon $\mathrm{G}$, de Foresta $\mathrm{H}$, Kusworo A dan $\mathrm{P}$ Levang. 2000. The Damar Agro-Forests of Krui, Indonesia: Justice for Forest Farmers. In C. Zerner (Editor): People, Plants and Justice. Columbia University Press. New York.
Pekon Pahmungan. 2017. Monografi Pekon Pahmungan. Pesisir Barat

Rahim dan Hastuti. 2007. Ekonomika Pertanian. Penebar Swadaya. Jakarta.

Soekartawi. 1995. Analisis Usahatani. UI Press. Jakarta.

Sugiarto. 2003. Teknik Sampling. Gramedia. Jakarta.

Suratiyah K. 2009. Ilmu Usahatani. Penebar Swadaya. Jakarta.

Thamrin SH, Sutjahjo, C Herison, dan S Biham. 2007. Analisis keberlanjutan wilayah perbatasan Kalimantan Barat-Malaysia untuk pengembangan kawasan agropolitan : studi kasus Kecamatan Bengkayang (dekat perbatasan Kabupaten Bengkayang). Jurnal Agro Ekonomi, 25 (2): 15-35. http://ejurnal.litbang.pertanian.go.id/index.ph p/jae/article/view/4716. [12 Juli 2019]. 